\title{
Reactivity of Trapped and Accumulated Electrons in Titanium Dioxide Photocatalysis
}

\author{
Shigeru Kohtani *, Akira Kawashima and Hideto Miyabe \\ Department of Pharmacy, School of Pharmacy, Hyogo University of Health Sciences, 1-3-6 Minatojima, Chuo-ku, \\ Kobe 650-8530, Japan; ak-kawashima@huhs.ac.jp (A.K.); miyabe@huhs.ac.jp (H.M.) \\ * Correspondence: kohtani@huhs.ac.jp; Tel.: +81-78-304-3158
}

Received: 20 September 2017; Accepted: 8 October 2017; Published: 13 October 2017

\begin{abstract}
Electrons, photogenerated in conduction bands (CB) and trapped in electron trap defects $\left(\mathrm{Ti}_{\mathrm{ds}}\right)$ in titanium dioxide $\left(\mathrm{TiO}_{2}\right)$, play crucial roles in characteristic reductive reactions. This review summarizes the recent progress in the research on electron transfer in photo-excited $\mathrm{TiO}_{2}$. Particularly, the reactivity of electrons accumulated in $\mathrm{CB}$ and trapped at $\mathrm{Ti}_{\mathrm{ds}}$ on $\mathrm{TiO}_{2}$ is highlighted in the reduction of molecular oxygen and molecular nitrogen, and the hydrogenation and dehalogenation of organic substrates. Finally, the prospects for developing highly active $\mathrm{TiO}_{2}$ photocatalysts are discussed.
\end{abstract}

Keywords: titanium dioxide; photocatalysis; surface defects; bulk defects; trapped electrons; accumulated electrons

\section{Introduction}

Since Fujishima and Honda discovered photoelectrochemical water splitting on titanium dioxide $\left(\mathrm{TiO}_{2}\right)$ photoelectrodes in the early $1970 \mathrm{~s}$ [1], $\mathrm{TiO}_{2}$ photocatalysis has been applied in various fields, such as the storage of solar energy [2-5], environmental purification [6], organic synthesis [7-11], anti-bacterial applications [12], and anti-fogging treatments [12,13]. These characteristic photo-functionalities are induced by incident light, in which the behavior of photogenerated electrons and holes, as well as the roles of defects formed on surface and in lattice, are of particular importance. The defect sites are the recombination centers for the photogenerated electrons and holes, because photocatalytic activities decrease with increasing the amount of defects created $[2,6,8]$. However, Amano et al. reported that the introduction of defect states in $\mathrm{TiO}_{2}$ with $\mathrm{H}_{2}$ reduction treatment greatly enhanced the photocatalytic activity for the water oxidation reaction in aqueous solution [14,15]. Moreover, Kong and coworkers claimed that tuning the relative concentration ratio of bulk defects/surface defects in $\mathrm{TiO}_{2}$ nanocrystal improves the separation efficiencies of photogenerated electrons and holes, thereby enhancing the photocatalytic activity [16]. Thus, further understanding of the defects in $\mathrm{TiO}_{2}$ necessitates the development of highly active photocatalysts.

The properties of defects-such as energy levels, structures, and interactions with adsorbates-have been reviewed by Diebold [17], Henderson [18], and Nowotny [19,20] in detail, but many unanswered questions remain. Recent studies in this field have made the considerable progress during the last decade. This review summarizes the recent progress in the research on the defects in $\mathrm{TiO}_{2}$. Herein, we focus on the properties of electron trap defects formed within the bandgap of $\mathrm{TiO}_{2}$ associated with Ti defects, specifically the intra-bandgap $\mathrm{Ti}$ states $\left(\mathrm{Ti}_{\mathrm{ds}}\right)$. Firstly, the fate of photogenerated electron and holes in $\mathrm{TiO}_{2}$ are described with respect to $\mathrm{Ti}_{\mathrm{ds}}$ and hole trap sites in Section 2. Next, the origin of $\mathrm{Ti}_{\mathrm{ds}}$ and their energy distribution in $\mathrm{TiO}_{2}$ are considered in Section 3. In Section 4 , the reactivity of electrons trapped at $\mathrm{Ti}_{\mathrm{ds}}$ and accumulated in the conduction band (CB) on the representative reductive reactions are highlighted. Finally, the prospect for developing a highly active $\mathrm{TiO}_{2}$ catalyst is discussed. 


\section{Fate of Photogenerated Electrons and Holes in $\mathrm{TiO}_{2}$}

Although several models exist for the charge transport, trapping, and the reaction of photogenerated electrons and holes on photoexcited $\mathrm{TiO}_{2}$, we adopted a schematic model for the anatase $\mathrm{TiO}_{2}$ based on the recent selected reviews and reports as illustrated in Figure 1 [11,21-25].

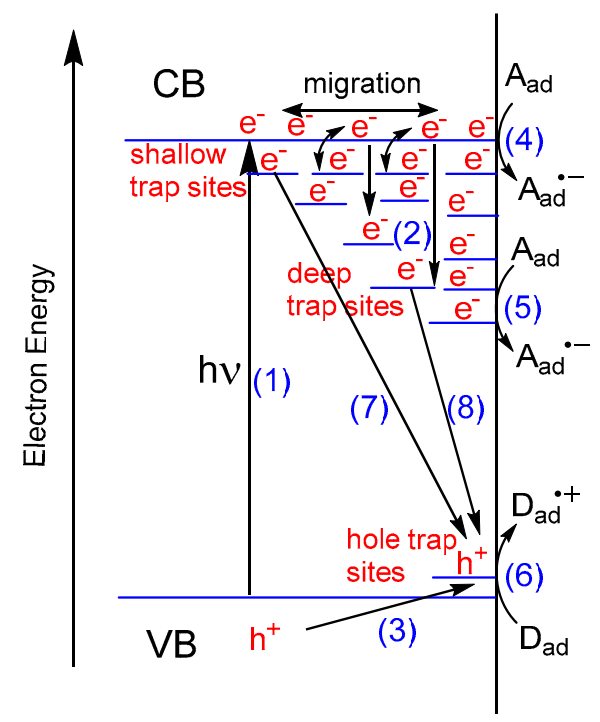

Figure 1. Schematic model of the earlier stage of photocatalysis in the anatase titanium dioxide $\left(\mathrm{TiO}_{2}\right)$. $\mathrm{CB}$ : conduction band; VB: valence band; $\mathrm{A}_{\mathrm{ad}}$ : adsorbed electron acceptor; $\mathrm{D}_{\mathrm{ad}}$ : adsorbed electron donor.

This model consists of several steps:

Step 1. Electron-hole pair generation

$$
\mathrm{TiO}_{2}+\mathrm{h} v \rightarrow \mathrm{TiO}_{2}\left(\mathrm{e}^{-}+\mathrm{h}^{+}\right)
$$

Step 2. Trapping $\mathrm{CB}$ electrons $\left(\mathrm{e}_{\mathrm{cb}}{ }^{-}\right)$at defect $\mathrm{Ti}^{4+}$ sites

$$
\mathrm{Ti}_{\mathrm{ds}}{ }^{4+}+\mathrm{e}_{\mathrm{cb}}{ }^{-} \rightarrow \mathrm{Ti}_{\mathrm{ds}}{ }^{3+}
$$

Step 3. Trapping valence band holes $\left(\mathrm{h}_{\mathrm{vb}}{ }^{+}\right)$at terminal Ti-OH or surface Ti-O-Ti sites

$$
\mathrm{Ti}^{-} \mathrm{O}_{\mathrm{s}} \mathrm{H} \text { or } \mathrm{Ti}-\mathrm{O}_{\mathrm{s}}-\mathrm{Ti}+\mathrm{h}_{\mathrm{vb}}{ }^{+} \rightarrow \mathrm{Ti}^{-} \mathrm{O}_{\mathrm{s}} \mathrm{H}^{+} \text {or } \mathrm{Ti}^{-} \mathrm{O}_{\mathrm{s}}{ }^{+}-\mathrm{Ti}
$$

Step 4. Reduction of adsorbed electron acceptor $\left(\mathrm{A}_{\mathrm{ad}}\right)$ with $\mathrm{e}_{\mathrm{cb}}{ }^{-}$at reduction sites

$$
\mathrm{e}_{\mathrm{cb}}{ }^{-}+\mathrm{A}_{\mathrm{ad}} \rightarrow \mathrm{A}_{\mathrm{ad}}{ }^{--}
$$

Step 5. Reduction of $\mathrm{A}_{\mathrm{ad}}$ with electrons trapped at defect sites $\left(\mathrm{Ti}_{\mathrm{ds}}{ }^{3+}\right)$

$$
\mathrm{Ti}_{\mathrm{ds}}{ }^{3+}+\mathrm{A}_{\mathrm{ad}} \rightarrow \mathrm{Ti}_{\mathrm{ds}}^{4+}+\mathrm{A}_{\mathrm{ad}}^{\cdot-}
$$

Step 6. Oxidation of adsorbed electron donor $\left(D_{a d}\right)$ by trapped holes at oxidation sites

$$
\mathrm{Ti}^{-} \mathrm{O}_{\mathrm{s}} \mathrm{H}^{++} \text {or } \mathrm{Ti}-\mathrm{O}_{\mathrm{s}}{ }^{++}-\mathrm{Ti}+\mathrm{D}_{\mathrm{ad}} \rightarrow \mathrm{Ti}^{-} \mathrm{O}_{\mathrm{s}} \mathrm{H} \text { or } \mathrm{Ti}-\mathrm{O}_{\mathrm{s}}-\mathrm{Ti}+\mathrm{D}_{\mathrm{ad}}{ }^{+} \quad([100 \mathrm{ps}-10 \mathrm{~ns}])
$$


Step 7. Recombination of $\mathrm{e}_{\mathrm{cb}}{ }^{-}$with trapped holes

$$
\mathrm{e}_{\mathrm{cb}}{ }^{-}+\mathrm{Ti}^{-} \mathrm{O}_{\mathrm{s}} \mathrm{H}^{+} \text {or } \mathrm{Ti}^{-\mathrm{O}_{\mathrm{s}}}{ }^{+}-\mathrm{Ti} \rightarrow \mathrm{Ti}^{-} \mathrm{O}_{\mathrm{s}} \mathrm{H} \text { or } \mathrm{Ti}-\mathrm{O}_{\mathrm{s}}-\mathrm{Ti}
$$

Step 8. Recombination of $\mathrm{Ti}_{\mathrm{ds}}{ }^{3+}$ with trapped holes

$$
\mathrm{Ti}_{\mathrm{ds}}{ }^{3+}+\mathrm{Ti}^{-} \mathrm{O}_{\mathrm{s}} \mathrm{H}^{+} \text {or } \mathrm{Ti}_{-} \mathrm{O}_{\mathrm{s}}{ }^{+}-\mathrm{Ti} \rightarrow \mathrm{Ti}_{\mathrm{dt}}{ }^{4+}+\mathrm{Ti}_{-}-\mathrm{O}_{\mathrm{s}} \mathrm{H} \text { or } \mathrm{Ti}-\mathrm{O}_{\mathrm{s}}-\mathrm{Ti}
$$

where time scales for each step are described in brackets [21-24]. The time scales depend on the crystalline phases, crystallinity, specific surface area, and the presence of bulk and surface defect states in $\mathrm{TiO}_{2}$. The following assumptions were applied to this model: (a) CB electrons $\left(\mathrm{e}_{\mathrm{cb}}{ }^{-}\right)$contain both electrons in CB and electrons trapped at shallow sites, located just below the CB edge of $\mathrm{TiO}_{2}$ within 0-0.05 eV. These electrons were assumed to be in thermal equilibrium in the bulk $\mathrm{CB}$ and at the shallow trap sites; (b) Valence band holes $\left(\mathrm{h}_{\mathrm{vb}}{ }^{+}\right)$are rapidly transported to the surface hole trap sites $\left(\mathrm{Ti}-\mathrm{O}_{\mathrm{s}} \mathrm{H}\right.$ or $\left.\mathrm{Ti}-\mathrm{O}_{\mathrm{s}}-\mathrm{Ti}\right)$ (Step 3); (c) trapped holes $\left(\mathrm{Ti}-\mathrm{O}_{\mathrm{s}} \mathrm{H}^{+}{ }^{+}\right.$or $\mathrm{Ti}-\mathrm{O}_{\mathrm{s}}{ }^{+}-\mathrm{Ti}$ ) are the main oxidants for the adsorbed electron donor $\left(\mathrm{D}_{\mathrm{ad}}\right)$ (Step 6); and (d) charge carrier recombination occurs between $\mathrm{e}_{\mathrm{cb}}{ }^{-}$and holes trapped at the surface trap sites (Step 7), as well as between electrons trapped at Ti defect states $\left(\mathrm{Ti}_{\mathrm{ds}}{ }^{3+}\right)$ and holes trapped at the surface trap sites (Step 8), whereas the interband electron-hole carrier recombination $\left(\mathrm{e}^{-}+\mathrm{h}^{+} \rightarrow \mathrm{hv}\right.$ or heat) is negligible.

These assumptions can be justified as follows. Tamaki and coworkers described the charge carrier dynamics under weak excitation conditions for nano-crystalline anatase $\mathrm{TiO}_{2}$ samples in femtosecond to microsecond time scales [22,23], which should be compatible with the actual photocatalytic reactions under the usual UV irradiation conditions. They observed the $\mathrm{e}_{\mathrm{cb}}{ }^{-}$and $\mathrm{h}_{\mathrm{vb}}{ }^{+}$pair generation within $100 \mathrm{fs}$, and the $\mathrm{e}_{\mathrm{cb}}{ }^{-}$migration between $\mathrm{CB}$ and shallow trap sites in equilibrium. These electrons then relaxed to deep trap sites $\left(\mathrm{Ti}_{\mathrm{ds}}\right)$ with an approximate $500 \mathrm{ps}$ time constant. Meanwhile, $\mathrm{h}_{\mathrm{vb}}{ }^{+}$ was rapidly trapped to the surface terminal $\mathrm{Ti}-\mathrm{O}_{\mathrm{s}} \mathrm{H}$ sites within $100 \mathrm{fs}$ to create $\mathrm{Ti}-\mathrm{O}_{\mathrm{s}} \mathrm{H}^{++}[22,23]$. If the photoinduced event occurred in alcohols, the lifetime of the $\mathrm{Ti}-\mathrm{O}_{\mathrm{s}} \mathrm{H}^{+}$generated on the $\mathrm{TiO}_{2}$ surface would be in the nanosecond or sub-nanosecond time scale (approximately 0.1-3 ns in alcohols) due to the fast reaction of $\mathrm{Ti}-\mathrm{O}_{\mathrm{s}} \mathrm{H}^{+}$with the abundant alcohol adsorbed on the $\mathrm{TiO}_{2}$ surface [24]. Therefore, the free $\mathrm{h}_{\mathrm{vb}}{ }^{+}$rarely presents in the bulk or on the surface of $\mathrm{TiO}_{2}$, so that $\mathrm{e}_{\mathrm{cb}}{ }^{-}$may recombine only with the trapped holes.

\section{Origin and Energy Distribution of Electron Trap Defects $\left(\mathrm{Ti}_{\mathrm{ds}}\right)$}

The bulk and surface $\mathrm{Ti}_{\mathrm{ds}}$ are formed in reduced or doped $\mathrm{TiO}_{2}$ in both rutile and anatase phases [17-20]. As depicted in Diebold's review [17], the bulk $\mathrm{Ti}_{\mathrm{ds}}$ are easily created in the rutile single crystal by thermal annealing in a vacuum, resulting in the formation of blue color centers, indicating high conductivity. Therefore, $\mathrm{TiO}_{2}$ is classified as an n-type semiconductor. The $\mathrm{H}_{2}$ reduction of $\mathrm{TiO}_{2}$ creates both oxygen vacancies and $\mathrm{Ti}^{3+}$ ions, which is an electron trapped in a $\mathrm{Ti}^{4+}$ lattice site, as described in Reaction (1) using Kröger-Vink notation [14,15,19,20]

$$
\mathrm{O}_{\mathrm{O}}^{\mathrm{x}}+2 \mathrm{Ti}_{\mathrm{Ti}}^{\mathrm{x}}+\mathrm{H}_{2} \rightarrow \mathrm{V}_{\mathrm{O}}^{\bullet \bullet}+2 \mathrm{Ti}^{\prime} \mathrm{Ti}+\mathrm{H}_{2} \mathrm{O}
$$

where $\mathrm{O}_{\mathrm{O}}^{\mathrm{x}}$ is an $\mathrm{O}^{2-}$ ion in the oxygen lattice site, $\mathrm{V}_{\mathrm{O}}^{\bullet \bullet}$ is an oxygen vacancy with a double positive charge, and $\mathrm{Ti}^{\prime}{ }_{\mathrm{Ti}}$ is a $\mathrm{Ti}^{3+}$ ion in the titanium lattice site. The two $\mathrm{Ti}^{\prime}$ Ti that are created per $\mathrm{V}_{\mathrm{O}}^{\bullet \bullet}$ have two excess electrons, which are responsible for the n-type conductivity, the blue-black colorization, and the enhancement of photocatalytic activity on $\mathrm{TiO}_{2}$. The $\mathrm{H}_{2}$ reduction on $\mathrm{TiO}_{2}$ can also induce a disordered structure in the surface layer of $\mathrm{TiO}_{2}$ nanocrystals, indicated by black $\mathrm{TiO}_{2}$ [26-28]. Black $\mathrm{TiO}_{2}$ exhibits high photocatalytic performance in decomposing organic pollutants and in generating hydrogen gas in an aqueous methanol solution under solar light irradiation. The other titanium oxides that have $\mathrm{Ti}_{\mathrm{ds}}$ are the F-doped or $\mathrm{Nb}$-doped $\mathrm{TiO}_{2}$, in which oxygen atoms are substituted with fluorine atoms or $\mathrm{Ti}$ atoms are replaced with $\mathrm{Nb}$ atoms, respectively [29]. Another type of $\mathrm{Ti}$ defect in $\mathrm{TiO}_{2}$ 
is titanium interstitials $\left(\mathrm{Ti}_{\mathrm{i}}^{\bullet \bullet \bullet}\right.$ ) possessing excess Ti atoms or ions in the lattice or in the near-surface region on $\mathrm{TiO}_{2}$ surface [17-20,30].

Facile laser ablation and processing techniques have been developed to introduce the defects into $\mathrm{TiO}_{2}$ nanocrystals and colloids in liquid [31-34]. In a typical procedure, $\mathrm{TiO}_{2}$ suspensions are irradiated by a high-intensity pulsed laser with frequent repetition rates to produce the characteristic blue-black $\mathrm{TiO}_{2}$. The obtained $\mathrm{TiO}_{2}$ nanoparticles enhanced the photocatalytic activities in decomposing an organic dye [31] and in a water splitting reaction [32].

The electronic energy of $\mathrm{Ti}_{\mathrm{ds}}$ is located just below the $\mathrm{CB}$ edge in the band gap of $\mathrm{TiO}_{2}$ in a broad range of $0-1.8 \mathrm{eV}$ [35]. Di Valentin and co-workers theoretically calculated the energy levels of point defects in bulk anatase $\mathrm{TiO}_{2}$, which are located at $0.3,0.4,0.7$, and $0.8 \mathrm{eV}$ below the CB edge, for six-fold-coordinated Ti introduced by $\mathrm{F}$ - or Nb-doping, Ti-OH species associated with hydrogen doping, five-coordinated $\mathrm{Ti}^{\prime} \mathrm{Ti}$ associated with the oxygen vacancy site, and titanium interstitials $\mathrm{Ti}_{\mathrm{i}}^{\bullet \bullet \bullet}$, respectively [29]. Deskins et al. calculated the relative energies of $\mathrm{Ti}_{\mathrm{ds}}$ formed in the $\{110\}$-terminated rutile $\mathrm{TiO}_{2}$ surface by means of the density functional theory (DFT), known as the DFT $+\mathrm{U}$ method $[36,37]$. They modeled the formation of $\mathrm{Ti}_{\mathrm{ds}}$ at various $\mathrm{Ti}$ sites, such as the five-coordinated Ti and oxygen vacancies [37]. The calculation for the five-coordinated $\mathrm{Ti}$ in the presence of surface hydroxyls indicated that deep $\mathrm{Ti}_{\mathrm{ds}}$ sites may exist in the second Ti layer from the surface or under the five-coordinated Ti rows [36].

The presence of these $\mathrm{Ti}_{\mathrm{ds}}$ species, such as $\mathrm{Ti}_{\mathrm{i}} / \mathrm{Ti}$ and $\mathrm{Ti}_{\mathrm{i}}^{\bullet \bullet \bullet}$, can be experimentally confirmed by means of electron spin resonance (ESR) [38-42], infrared radiation (IR) [40,42-48], ultraviolet-visible absorption (UV-vis) [14,42,49-51], photoluminescence (PL) [52], photoacoustic [53-56], and photoelectron spectroscopies [17,18,30]. Scanning tunneling microscopy (STM) and atomic force microscopy (AFM) are powerful tools for the direct observation of surface $\mathrm{Ti}_{\mathrm{ds}}[17,18,30,57-59]$. The oxygen vacancy $\left(\mathrm{Ti}^{\prime} \mathrm{Ti}_{\mathrm{i}}\right.$ accompanied by $\mathrm{V}_{\mathrm{O}}^{\bullet \bullet}$ ) [57-59] and interstitial $\mathrm{Ti}\left(\mathrm{Ti}_{\mathrm{i}}^{\bullet \bullet \bullet}\right.$ ) [30] sites were directly observed on the $\mathrm{TiO}_{2}$ surface.

The $\mathrm{Ti}_{\mathrm{ds}}$ described above are not the only type of point defects. There are many types of lattice defects including step edges, line defects, grain boundaries, and impurities [17]. The $\mathrm{Ti}_{\mathrm{ds}}$ energies can be strongly affected by site heterogeneity due to the local structures. Furthermore, under actual photocatalytic conditions, the $\mathrm{TiO}_{2}$ surface is always covered by adsorbates, especially solvent molecules; thus, the energy of $\mathrm{Ti}_{\mathrm{ds}}$ should depend on the adsorbed species $[19,20]$. Therefore, the information from the theoretical calculations and the photoelectron spectroscopy, applied to the clean catalyst surfaces under ultra-high vacuum conditions, may be limited for actual photocatalytic systems. To address this issue, Ohtani et al. developed a powerful tool for measuring the energy-resolved distribution of electron trap states for many types of $\mathrm{TiO}_{2}$ powders, composed of anatase, rutile, and brookite in methanol-containing gas phase, by means of reversed double-beam photoacoustic spectroscopy (RDB-PAS) [56]. They showed that the electron energy of the trap states is distributed around the $\mathrm{CB}$ edge of $\mathrm{TiO}_{2}$ and the distribution range of anatase $\mathrm{TiO}_{2}$ is relatively broader than that of rutile $\mathrm{TiO}_{2}$ (Figure 2). The energy distribution patterns for both anatase and rutile $\mathrm{TiO}_{2}$ powders are similar to those obtained by the photochemical method, which uses the surface reaction of the trapped electrons with methyl viologen to release its cation radical in de-aerated aqueous solution containing methanol as a sacrificial reagent [60]. They also revealed that the total density of the traps is well-correlated to the specific surface area of $\mathrm{TiO}_{2}$ powders, suggesting that the electron trap sites are predominantly located on the surface of $\mathrm{TiO}_{2}$, and they do not depend on the type of crystallites in anatase, rutile, or their mixtures. 


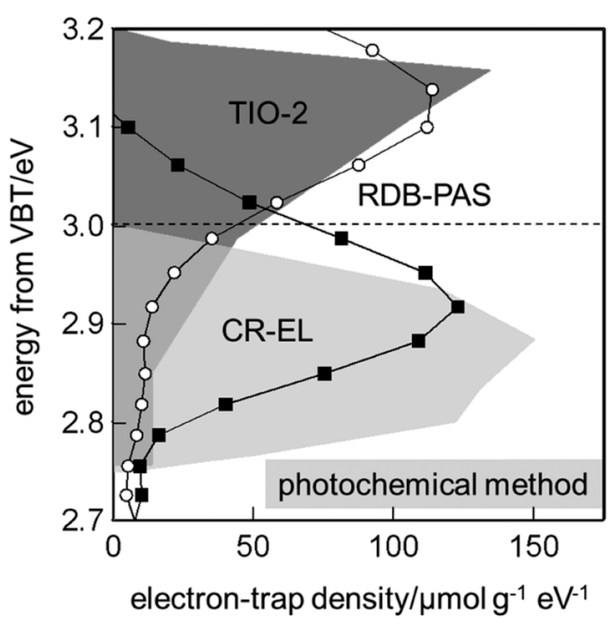

Figure 2. Comparison of energy-resolved distribution of electron traps (ERDT) patterns measured using the photochemical method shown by the grey patterns [60], and reversed double-beam photoacoustic spectroscopy (RDB-PAS), shown by the plots [56], for representative anatase $\left(\mathrm{TIO}^{-2} ; 18 \mathrm{~m}^{2} \mathrm{~g}^{-1}\right.$ ) and rutile $\left(7 \mathrm{~m}^{2} \mathrm{~g}^{-1}\right)$ samples. The top line, at $3.2 \mathrm{eV}$, and the dashed line show the conduction bands (CB) edge positions of anatase and rutile estimated by the reported bandgaps at 3.2 and $3.0 \mathrm{eV}$, respectively. Reprinted from reference [56], an open access article under conditions of the Creative Commons Attribution (CC BY) license.

The energy distribution of $\mathrm{Ti}_{\mathrm{ds}}$ can also be obtained by an electrochemical method [61,62]. In this method, the potential variation in accumulated charge at the $\mathrm{TiO}_{2}$ electrode can be measured in aqueous solution. By calculating the derivative of the accumulated charge $(Q)$ versus the applied potential $(U)$, the energy density of $T_{\mathrm{ds}}$ is directly proportional to $\mathrm{d} Q / \mathrm{d} U$ and the plot of $\mathrm{d} Q / \mathrm{d} U$ vs. $U$ reflects the energy distribution of $\mathrm{Ti}_{\mathrm{ds}}$. The maximum density of $\mathrm{Ti}_{\mathrm{ds}}$ is located around $0.25-0.4 \mathrm{eV}$ below the $\mathrm{CB}$ edge for nanostructured anatase $\mathrm{TiO}_{2}$ and $\mathrm{P} 25 \mathrm{TiO}_{2}$ samples with a ratio of anatase to rutile of approximately 80:20. Thus, the distribution of $\mathrm{Ti}_{\mathrm{ds}}$ within $0-0.4 \mathrm{eV}$ is predominant, so that electrons trapped in these trap states may participate in the reductive reaction on $\mathrm{TiO}_{2}$.

\section{Reactivity of Trapped and Accumulated Electrons}

This section highlights the reactivity of electrons trapped at $\mathrm{Ti}_{\mathrm{ds}}$ and accumulated in $\mathrm{CB}$ in the reductions of molecular oxygen $\mathrm{O}_{2}$ and molecular nitrogen $\mathrm{N}_{2}$, and the hydrogenation and dehalogenation of selected organic substrates occurring on $\mathrm{TiO}_{2}$. The reductive reactions associated with $\mathrm{Ti}_{\mathrm{ds}}$ have been extensively investigated under various experimental conditions and through theoretical calculation methods. Although many studies have been performed for clean surfaces on $\mathrm{TiO}_{2}$ under high-vacuum conditions $[17,18,30,57-59]$, here we focus on the reactions occurring on powder or colloidal $\mathrm{TiO}_{2}$ under conventional gas or liquid phase conditions.

Here we define the terms 'accumulated electrons' $\left(\mathrm{e}_{\mathrm{cb}}{ }^{-}\right)$and 'trapped electrons' $\left(\mathrm{Ti}_{\mathrm{ds}}{ }^{3+}\right)$ to distinguish them. Accumulated electrons contain both electrons in $\mathrm{CB}$ and electrons trapped at shallow Ti states, located just below the $\mathrm{CB}$ edge of $\mathrm{TiO}_{2}$, within $0-0.05 \mathrm{eV}$. These electrons can be in thermal equilibrium between the bulk $\mathrm{CB}$ and at the shallow trap sites, and easily migrate through these states. The accumulation of electrons in these states should occur after saturation of the intra-bandgap Ti states $\left(\mathrm{Ti}_{\mathrm{ds}}\right)$ during UV irradiation. These electrons are highly reactive at the $\mathrm{TiO}_{2}$ interface (Step 4 in Figure 1).The trapped electrons $\mathrm{Ti}_{\mathrm{ds}}{ }^{3+}$ mean the electrons trapped at $\mathrm{Ti}_{\mathrm{ds}}$ are located in relatively deep energy from the $\mathrm{CB}$ edge. Therefore, the trapped electrons $\mathrm{Ti}_{\mathrm{ds}}{ }^{3+}$ cannot be excited thermally to the $\mathrm{CB}$ or the shallow states, exhibiting either low or no reactivity at the $\mathrm{TiO}_{2}$ interface (Step 5 in Figure 1).

The trapped electrons $\mathrm{Ti}_{\mathrm{ds}}{ }^{3+}$ and the accumulated electrons $\mathrm{e}_{\mathrm{cb}}{ }^{-}$are quite stable in the presence of a good sacrificial hole scavenger, such as alcohols or amines, and in the absence of electron acceptors 
such as $\mathrm{O}_{2}$, the lifetime may exceed several hours [50,51,63]. This extremely long lifetime of $\mathrm{Ti}_{\mathrm{ds}}{ }^{3+}$ and $\mathrm{e}_{\mathrm{cb}}{ }^{-}$is attributable to the excellent hole scavenging ability of the sacrificial reagents on the $\mathrm{TiO}_{2}$ surface [24], which prevents the recombination of $\mathrm{Ti}_{\mathrm{ds}}{ }^{3+}$ and $\mathrm{e}_{\mathrm{cb}}{ }^{-}$with the surface trapped holes. In other words, the hole scavengers inhibit Steps 7 and 8 in Figure 1. The excess charges caused by electrons $\mathrm{Ti}_{\mathrm{ds}}{ }^{3+}$ and $\mathrm{e}_{\mathrm{cb}}{ }^{-}$on the irradiated $\mathrm{TiO}_{2}$ are balanced by the insertion (intercalation) of protons into the $\mathrm{TiO}_{2}$ lattice $[47,62,64,65]$. The electrons $\mathrm{Ti}_{\mathrm{ds}}{ }^{3+}$ and $\mathrm{e}_{\mathrm{cb}}{ }^{-}$show the unique blue-black coloration from the visible to the IR region $[14,40,42-51]$, which enables the tracing of the lifetimes of the species generated on the irradiated $\mathrm{TiO}_{2}$. Interestingly, the electrons $\mathrm{Ti}_{\mathrm{ds}}{ }^{3+}$ and $\mathrm{e}_{\mathrm{cb}}{ }^{-}$are distinguishable by measuring IR spectra. The free electrons $\mathrm{e}_{\mathrm{cb}}{ }^{-}$exhibit the typical exponential frequency-dependent spectrum that is attributed to the intra-CB transition $[43,44,46,48]$, whereas the trapped electrons $\mathrm{Ti}_{\mathrm{ds}}{ }^{3+}$ are characterized by a broad absorption in the mid-IR region that is ascribed to a direct optical transition $[46,48]$.

\subsection{Reduction of Molecular Oxygen and Hydrogen Peroxide}

The interfacial electron transfer between molecular oxygen $\left(\mathrm{O}_{2}\right)$ and electrons $\mathrm{Ti}_{\mathrm{ds}}{ }^{3+}$ or $\mathrm{e}_{\mathrm{cb}}{ }^{-}$ on nanocrystalline $\mathrm{TiO}_{2}$ films was examined using a transient UV-vis absorption spectroscopy in gas phase [66]. In the presence of ethanol, as a sacrificial hole scavenger under ethanol-saturated conditions $(5.8 \%)$, the half-life $\left(t_{50 \%}\right)$ of the electron-species $\mathrm{Ti}_{\mathrm{ds}}{ }^{3+}$ and $\mathrm{e}_{\mathrm{cb}}{ }^{-}$was approximately $0.5 \mathrm{~s}$ in the absence of $\mathrm{O}_{2}$. The $t_{50 \%}$ value drastically decreased with increasing $\mathrm{O}_{2}$ concentration, to approximately $12 \mu \mathrm{s}$ in an oxygen concentration of $21 \%$ (air saturated conditions). Thus, the efficient electron transfer of molecular oxygen in a gaseous phase occurred on $\mathrm{TiO}_{2}$ films by using ethanol as the hole scavenger. The dynamics of the electron transfer between $\mathrm{O}_{2}$ and the nanosized $\mathrm{TiO}_{2}$ particles in a liquid phase were also investigated by employing a simple and facile stopped flow technique [50,51]. With methanol as the hole scavenger, the electrons on the $\mathrm{TiO}_{2}$ particles, in an argon-purged and de-aerated aqueous solution, were accumulated by pre-UV irradiation, causing blue colorization characterized by a broad absorption band in the visible light region of $400-800 \mathrm{~nm}$. In the stopped flow experiment, the $\mathrm{TiO}_{2}$ solution containing the electron-species $\mathrm{Ti}_{\mathrm{ds}}{ }^{3+}$ and $\mathrm{e}_{\mathrm{cb}}{ }^{-}$ was mixed with the aqueous solution containing $\mathrm{O}_{2}$ at $\mathrm{pH} 2.3$, and the change in absorbance of the electrons was recorded at $600 \mathrm{~nm}$. The absorbance signal decreased slowly with a rate constant of $8.9 \times 10^{-7} \mathrm{~mol} \mathrm{~L}^{-1} \mathrm{~s}^{-1}$ in the absence of $\mathrm{O}_{2}$, whereas the signal rapidly disappeared within a few seconds under $\mathrm{O}_{2}$-saturated conditions. Thus, efficient electron transfer from the accumulated $\mathrm{TiO}_{2}$ to $\mathrm{O}_{2}$ proceeded even in the aqueous solution. The reduction of hydrogen peroxide $\left(\mathrm{H}_{2} \mathrm{O}_{2}\right)$ was also confirmed by the same stopped flow experiment [50,51]. The decay rate of the electron-species $\mathrm{Ti}_{\mathrm{ds}}{ }^{3+}$ and $\mathrm{e}_{\mathrm{cb}}{ }^{-}$in the $\mathrm{H}_{2} \mathrm{O}_{2}$ reduction was slower than in the $\mathrm{O}_{2}$ reduction under similar conditions.

The reduction of $\mathrm{O}_{2}$ on $\mathrm{TiO}_{2}$ results in the formation of reactive oxygen species (ROS), such as superoxide anion radicals $\left(\mathrm{O}_{2}{ }^{-}\right)$, hydroperoxy radicals $(\cdot \mathrm{OOH})$, hydrogen peroxide $\left(\mathrm{H}_{2} \mathrm{O}_{2}\right)$, and hydroxyl radicals $(\cdot \mathrm{OH})$, under both aqueous and aerated conditions [6,21]. These ROS play a crucial role in the photocatalysis on $\mathrm{TiO}_{2}$ for water purification, air cleaning, self-cleaning, self-sterilization, etc. The sequential ROS generation on photo-irradiated $\mathrm{TiO}_{2}$ under acidic conditions can be depicted as follows $[6,21,50,51]$ :

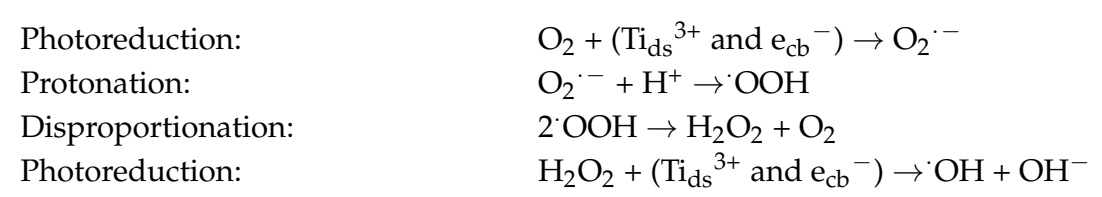

Though the CB edge of anatase $\mathrm{TiO}_{2}$ is located at $-0.27 \mathrm{~V}$ vs. standard hydrogen electrode (SHE) at $\mathrm{pH} 2.3$ [67], anatase $\mathrm{TiO}_{2}$ produced the superoxide anion radial by photoexcitation; $\mathrm{O}_{2} / \mathrm{O}_{2}{ }^{--}$ was approximately $0.33 \mathrm{~V}$ vs. SHE [68]. This could be due to the strong adsorption of $\mathrm{O}_{2}$ at the

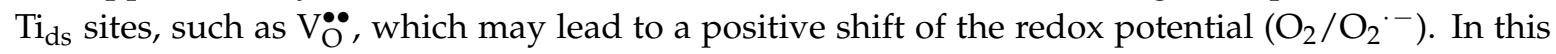
electron transfer step, an electron seems to be transferred from the Ti $3 \mathrm{~d}$ orbital to the $\pi^{*}$ orbital of the adsorbed $\mathrm{O}_{2}$. 


\subsection{Reduction of Molecular Nitrogen, Nitrate, and Nitrite Ions}

Molecular nitrogen $\left(\mathrm{N}_{2}\right)$ is chemically stable, so photocatalytic reduction of $\mathrm{N}_{2}$ to ammonia $\left(\mathrm{NH}_{3}\right)$ under ambient temperature and pressure is challenging. Hirakawa and coworkers recently reported that the photocatalytic conversion of $\mathrm{N}_{2}$ to ammonia with water occurred on the bare $\mathrm{TiO}_{2}$ powders under ambient conditions [69]. They stated that the active sites for $\mathrm{N}_{2}$ reduction are the $\mathrm{Ti}_{\mathrm{ds}}$ with oxygen vacancies mainly formed on the rutile $\{110\}$ surface. They investigated the photocatalytic reductions of nitrate $\left(\mathrm{NO}_{3}{ }^{-}\right)$and nitrite $\left(\mathrm{NO}_{2}{ }^{-}\right)$ions to ammonia and $\mathrm{N}_{2}$ on bare $\mathrm{TiO}_{2}$ under ambient conditions [70]. They proposed that the $\mathrm{Ti}_{\mathrm{ds}}$ sites selectively promoted the eight-electron reduction of $\mathrm{NO}_{3}{ }^{-}$to $\mathrm{NH}_{3}\left(\mathrm{NO}_{3}{ }^{-}+9 \mathrm{H}^{+}+8 \mathrm{e}^{-} \rightarrow \mathrm{NH}_{3}+3 \mathrm{H}_{2} \mathrm{O}\right)$, while the Lewis acid site promoted nonselective reduction, resulting in $\mathrm{N}_{2}$ and $\mathrm{NH}_{3}$ formation. Thus, $\mathrm{TiO}_{2}$ with many $\mathrm{Ti}_{\mathrm{ds}}$ and a small number of Lewis acid sites produced ammonia with very high selectivity. The use of artificial fertilizers in agriculture has caused a great deal of concern for water pollution caused by the production of $\mathrm{NO}_{3}{ }^{-}$and $\mathrm{NO}_{2}{ }^{-}$ ions from fertilizers [71]. Therefore, a chemical process for the reduction of $\mathrm{NO}_{3}{ }^{-}$and $\mathrm{NO}_{2}{ }^{-}$ions on $\mathrm{TiO}_{2}$ may be useful for an environmental recycling process.

\subsection{Hydrogenation of Carbonyl Compounds}

Kohtani et al. examined whether electrons $\mathrm{Ti}_{\mathrm{ds}}{ }^{3+}$ and $\mathrm{e}_{\mathrm{cb}}{ }^{-}$transfer to acetophenone (AP) derivatives adsorbed on $\mathrm{TiO}_{2}[63,72]$. The photoreductive hydrogenation of several aromatic carbonyl compounds was confirmed to occur on UV-irradiated $\mathrm{P} 25 \mathrm{TiO}_{2}$ as illustrated in Scheme 1 [72,73]. They evaluated the number of transferred electrons in the injection experiment using a pre-irradiated $\mathrm{TiO}_{2}$ suspension. When the $\mathrm{P} 25 \mathrm{TiO}_{2}$ powder was dispersed in de-aerated ethanol as a hole scavenger and irradiated with UV light for $2 \mathrm{~h}$, the white color of $\mathrm{TiO}_{2}$ powder changed to blue-gray. After the blue-gray color change was confirmed, a large amount of AP derivatives was injected into this $\mathrm{TiO}_{2}$ suspension in the dark. In this experiment, ethanol acted not only as a solvent but also as a hole scavenger.

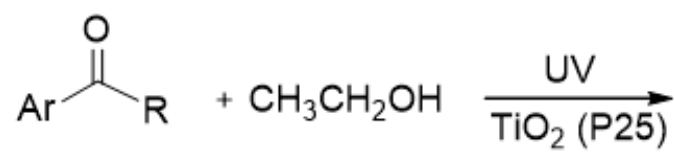<smiles>[R]C(O)[Al]</smiles>

Scheme 1. Photocatalytic hydrogenation of aromatic carbonyl compounds: Ar = aromatic ring, $R=H$, $\mathrm{Me}, \mathrm{Et}, i-\mathrm{Pr}$, or $\mathrm{CF}_{3}$. Reprinted with permission from reference [72]. Copyright (2014) The Royal Society of Chemistry.

Figure 3a shows that the blue-gray color of the pre-irradiated $\mathrm{P} 25 \mathrm{TiO}_{2}$ suspension remained for a few days in the absence of AP derivatives [63], meaning that the electrons accumulated on the P25 $\mathrm{TiO}_{2}$ surface are quite stable in the de-aerated ethanol. Figure $3 \mathrm{~b}, \mathrm{c}$ show the color change induced by the addition of aromatic carbonyl compounds. The blue-gray color of $\mathrm{TiO}_{2}$ rapidly changed after the injection of 2,2,2-trifluoacetophenone (TFAP) where the aromatic ring (Ar) was $\mathrm{C}_{6} \mathrm{H}_{5}$ and the $\mathrm{R}$ was $\mathrm{CF}_{3}$ (Scheme 1). The change from blue-gray to white was completed within $3 \mathrm{~h}$ in the TFAP solution as shown in Figure 3c. This result indicates that all the trapped and accumulated electrons on $\mathrm{TiO}_{2}$ were consumed in the reduction of TFAP within $3 \mathrm{~h}$. On the other hand, with AP, a part of the blue-gray species on $\mathrm{TiO}_{2}$ was remarkably stable even after $50 \mathrm{~h}$, as shown in Figure 3b, which may be due to the remaining electrons trapped at the deep states of $\mathrm{TiO}_{2}$. 

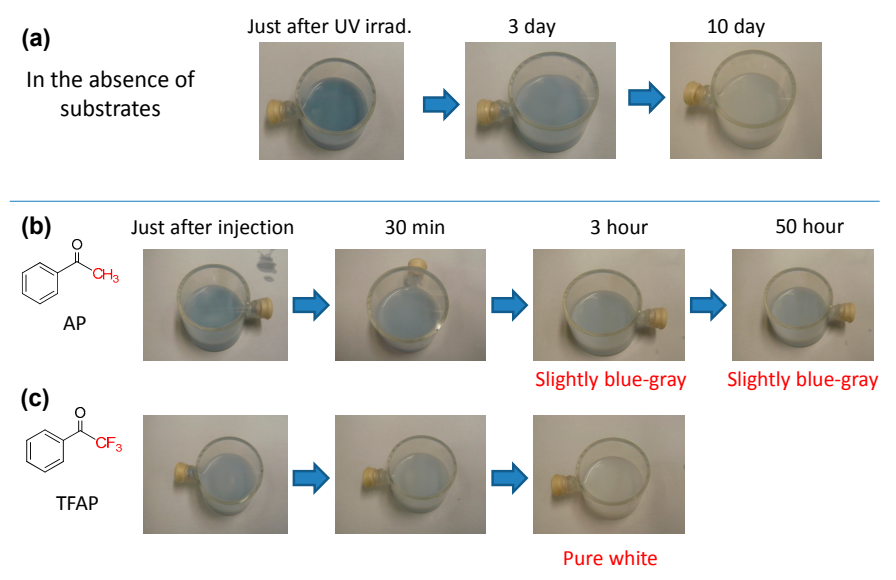

Figure 3. Color changes of the pre-irradiated $\mathrm{P} 25 \mathrm{TiO}_{2}$ powder dispersed in de-aerated ethanol (a) in the absence of substrates, and after injection of (b) $300 \mu \mathrm{mol}$ acetophenone (AP), or (c) 2,2,2-trifluoacetophenone (TFAP). Adapted with permission from reference [63]. Copyright 2012 American Chemical Society. UV irrad.: UV irraditaion.

Figure 4 depicts the time evolution of the secondary alcohols 1-phenylethanol (AP-OH) or 1-phenyl-2,2,2-trifluoroethanol (TFAP-OH), as products after the injection of substrates AP or TFAP, into the sufficient pre-irradiated $\mathrm{TiO}_{2}$ suspension, respectively [63]. The amount of each product quickly grew within $0.5 \mathrm{~h}$, which agrees with the observation of color change in the $\mathrm{TiO}_{2}$ suspension (Figure $3 b, c)$. The amount of TFAP-OH product obtained from the reactive substrate TFAP rapidly increased, and reached $5.4 \mu \mathrm{moL}$ within $1 \mathrm{~h}$. Assuming all $\mathrm{Ti}_{\mathrm{ds}}{ }^{3+}$ and $\mathrm{e}_{\mathrm{cb}}{ }^{-}$electrons were consumed in the reductive hydrogenation of TFAP, the total amount of $\mathrm{Ti}_{\mathrm{ds}}{ }^{3+}$ and $\mathrm{e}_{\mathrm{cb}}{ }^{-}$on the $\mathrm{TiO}_{2}$ powder was estimated to be about $100 \mu \mathrm{mol} \cdot \mathrm{g}^{-1}$. The time evolution of AP-OH from the less reactive substrate $\mathrm{AP}$ consisted of a fast component within $0.5 \mathrm{~h}$, and a slow component after $0.5 \mathrm{~h}$, which increased gradually to reach $4.1 \mu \mathrm{mol}$ (Figure 4). The slow component represents the slow electron transfer event from middle $\mathrm{Ti}_{\mathrm{ds}}$, between shallow and deep states, to $\mathrm{AP}$ adsorbed on $\mathrm{TiO}_{2}$. The total amount of AP-OH production was about $25 \%$ smaller than that of TFAP-OH production. In the reduction of the less reactive substrate $\mathrm{AP}$, the deep $\mathrm{Ti}_{\mathrm{ds}}{ }^{3+}$ species remained on the $\mathrm{TiO}_{2}$ surface for a long time $(>20 \mathrm{~h})$ after the injection of AP. The amount of deep $\mathrm{Ti}_{\mathrm{ds}}{ }^{3+}$ that remained on $\mathrm{TiO}_{2}$ was roughly estimated to be $25 \%$ given the difference between the amounts of TFAP-OH $(5.4 \mu \mathrm{moL})$ and AP-OH $(4.1 \mu \mathrm{moL})$. Thus, the residual $25 \%$ electrons could not react with AP and remained at the deep trap sites.

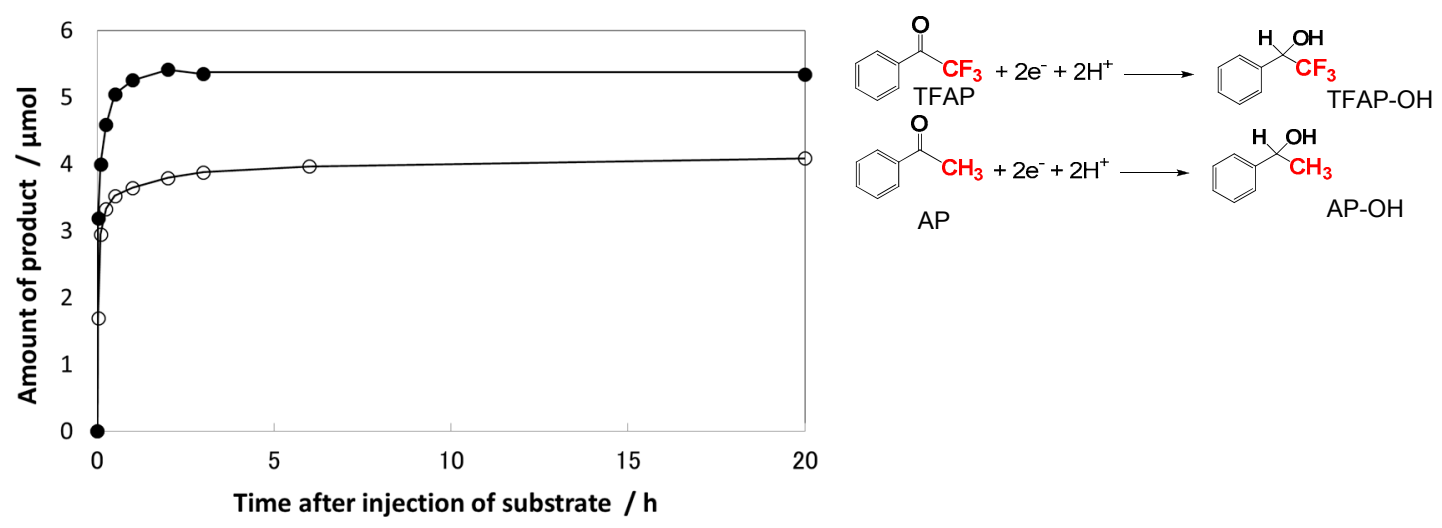

Figure 4. Time evolutions of the amount of AP-OH $(\bigcirc)$ and TFAP-OH $(\bullet)$ after the $300 \mu$ mol injection of substrate (AP or TFAP) into the $2 \mathrm{~h}$ pre-irradiated $\mathrm{TiO}_{2}$ suspension at $32{ }^{\circ} \mathrm{C}$ Adapted with permission from reference [63]. Copyright (2012) American Chemical Society. 
Assuming that all $\mathrm{Ti}_{\mathrm{ds}}{ }^{3+}$ and $\mathrm{e}_{\mathrm{cb}}{ }^{-}$electrons react with TFAP, the percentages of reacted electrons were estimated for other AP derivatives, as summarized in Table 1 [72]. The number of reacted electrons showed a tendency to decrease with decreasing the reduction potential $\left(E_{\text {red }}\right)$ of the substrates according to the dependence on the actual reaction rates as listed in Table 1 . This implies that the rates of photocatalytic hydrogenation of AP derivatives are governed by the electron transfer efficiency from the $\mathrm{Ti}_{\mathrm{ds}}$ sites to the adsorbed AP sites. Notably, the relative position between the $\mathrm{Ti}_{\mathrm{ds}}$ energy distributed within the bandgap and the acceptor level of the AP derivatives (the solid Gaussian curve) should be appropriate (Figure 5) [72]. The energy distribution of $\mathrm{Ti}_{\mathrm{ds}}$ in $\mathrm{TiO}_{2}$ powders and colloids can be obtained by photochemical [60], electrochemical [61,62], and RDB-PAS [56] methods. The acceptor levels of AP derivatives can be estimated by the Marcus theory [72,74-76].

Table 1. Reduction potentials, amount of reacted electrons, percentages of reacted electrons, and reaction rates at maximum concentration of substrates [72]. Adapted with permission from reference [72]. Copyright (2014) The Royal Society of Chemistry.

\begin{tabular}{|c|c|c|c|c|}
\hline Substrate & $E_{\mathrm{red}} / \mathrm{V}^{a}$ & $\begin{array}{l}\text { Amount of Reacted } \\
\text { Electrons } b / \mu \mathrm{moL}\end{array}$ & Percentage $c / \%$ & Reaction Rate ${ }^{d} / \mathrm{mMh}^{-1}$ \\
\hline 1 (TFAP) & -1.35 & 10.2 & 100 & - \\
\hline 2 & -1.59 & 8.22 & 81 & $3.4 \pm 0.2$ \\
\hline 3 & -1.62 & 6.32 & 62 & $2.2 \pm 0.2$ \\
\hline 4 & -1.80 & 6.09 & 60 & $2.0 \pm 0.1$ \\
\hline $5(\mathrm{AP})$ & -1.89 & 7.38 & 72 & $1.9 \pm 0.1$ \\
\hline 6 & -0.92 & 5.70 & 56 & $1.2 \pm 0.1$ \\
\hline 7 & -1.94 & 4.76 & 47 & $0.75 \pm 0.05$ \\
\hline
\end{tabular}

${ }^{a}$ Reduction potentials vs. SHE (standard hydrogen electrode). ${ }^{b}$ Molar number of reacted electrons estimated by the injection experiment using a pre-irradiated $\mathrm{TiO}_{2}$ suspension. ${ }^{c}$ Percentage of the reacted electrons per the total amount of $\mathrm{Ti}_{\mathrm{st}^{3+}}{ }^{3+}$ and $\mathrm{e}_{\mathrm{cb}}-(10.2 \mu \mathrm{mol})$ generated on $0.10 \mathrm{~g} \mathrm{TiO}_{2} .{ }^{d}$ Reaction rates at the maximum concentration of substrates.

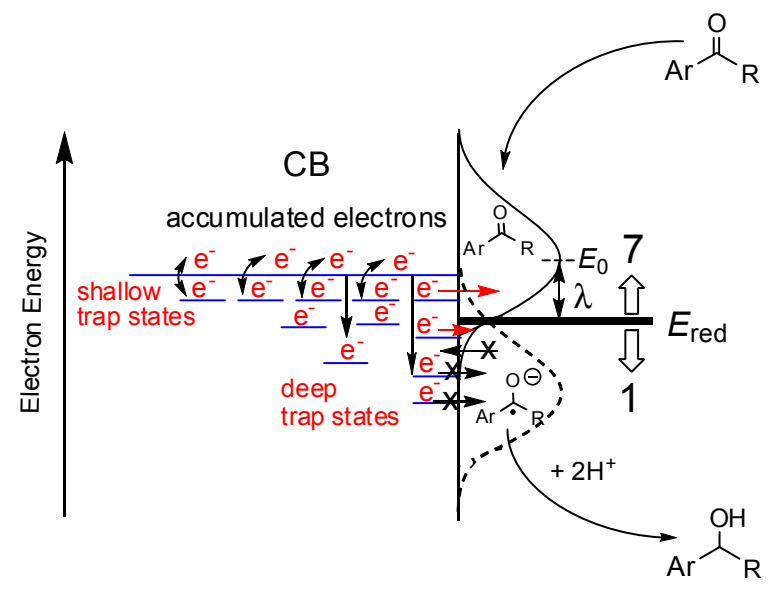

Figure 5. Schematic illustration of the electron transfer reaction from the $\mathrm{Ti}_{\mathrm{ds}}$ states to the adsorbed AP derivatives, where $E_{\text {red }}$ is the reduction potential of AP derivatives, $\lambda$ is the reorganization energy (approximately $0.7 \mathrm{eV}$ for $\mathrm{AP}$ ), and $E_{0}$ is the energy at the top of curve for the acceptor level, calculated by $q E_{\text {red }}-\lambda$ and shown by the solid line. The dotted line indicates the donor energy level for anionic species. Reprinted with permission from reference [72]. Copyright (2014) The Royal Society of Chemistry. 
Kohtani et al. also reported the photohydrogenation of AP derivatives on $\mathrm{P} 25 \mathrm{TiO}_{2}$, modified with metal-free organic dyes such as rhodamine B, fluorescein, and coumarin derivatives $[77,78]$. The use of these organic dyes successfully extended the UV response of $\mathrm{TiO}_{2}$ to the visible light region, though these reaction rates were much slower than the hydrogenation rate using UV excitation of non-modified $\mathrm{TiO}_{2}$. In this dye-sensitized system, the electron injection from dye into $\mathrm{TiO}_{2}$ can take place in two different ways: (1) injection via a lowest unoccupied molecular orbital (LUMO) level of the excited dye to the $\mathrm{CB}$ of $\mathrm{TiO}_{2}$, and (2) direct injection of $\mathrm{TiO}_{2}$ to $\mathrm{CB}$ on the excitation of the charge transfer complex $\left(\mathrm{TiO}_{2}{ }^{\delta-} \mathrm{dye}^{\delta+}\right)$ [77]. The injected electrons should then be distributed to the $\mathrm{Ti}_{\mathrm{ds}}$ sites on the $\mathrm{P} 25 \mathrm{TiO}_{2}$ surface. The accumulated electrons were observed with the blue-gray color for all dye- $\mathrm{TiO}_{2}$ powders during visible light irradiation.

\subsection{Defluorination of Fluorinated AP Derivatives}

Compounds containing fluorine atoms are often used as pharmaceutical and agrochemical reagents. Since the C-F bond is one of the strongest bonds, C-F bond activation and cleavage is a field of current interest in organic chemistry [79], although less is known about the catalytic activation and cleavage methods. Photocatalytic reaction is one of the promising methods to promote the activation and cleavage of the $\mathrm{C}-\mathrm{F}$ bond of fluorinated compounds under mild conditions. Therefore, an attempt was made to use trapped and accumulated electrons on $\mathrm{TiO}_{2}$ for the sequential multi-step electron transfer in the reduction of fluorinated AP derivatives (Figure 6) [80]. The reaction of fluorinated AP derivatives on $\mathrm{TiO}_{2}$ showed the two photocatalytic reductive transformations, i.e., the defluorination and reduction of the carbonyl group. The reduction of 2-fluoromethylacetophenone (MFAP) only provided the ketone AP because of the $\mathrm{C}-\mathrm{F}$ bond cleavage, whereas the reaction of TFAP only provided the alcohol TFAP-OH as a result of the reduction of the carbonyl group. Interestingly, the reduction of 2,2-difluoromethyacetophenone (DFAP), possessing characteristics between those of MFAP and TFAP, gave the defluorinated ketones, MFAP and AP, as well as hydrogenated alcohol 1-phenyl-2,2-difluoroethanol (DFAP-OH), as shown in Figure 6. The defluorination reactions became unfavorable with increasing the number of fluorine atoms on the substrates. This mainly arises because of the increase in the bond dissociation energy of the $\mathrm{C}-\mathrm{F}$ bond and the positive shift of the reduction potential of fluorinated AP derivatives with the increasing number of fluorine atoms [80].

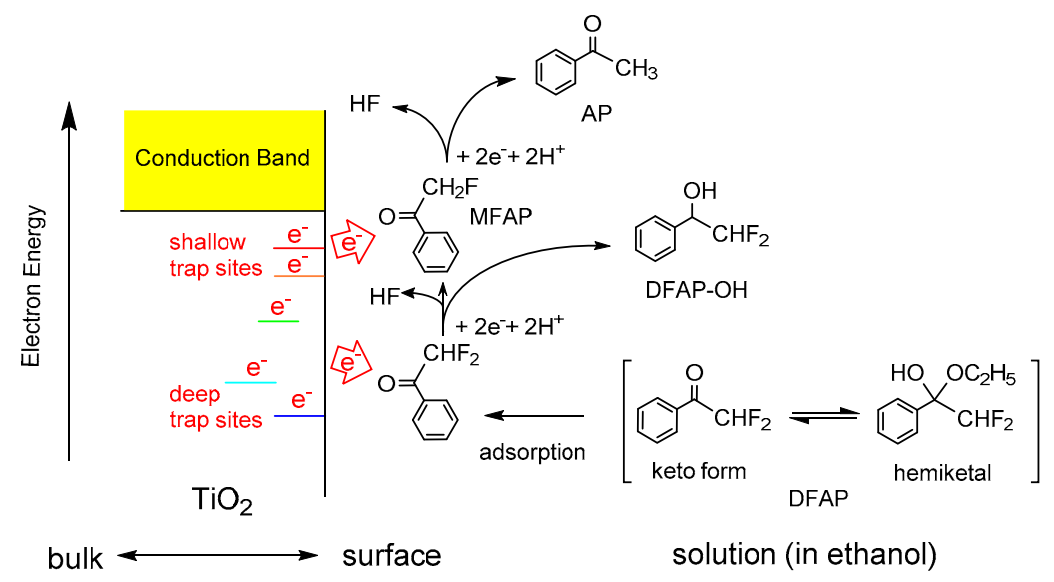

Figure 6. Schematic illustration on the photocatalytic reduction of 2,2-difluoromethyacetophenone (DFAP) on the UV irradiated $\mathrm{TiO}_{2}$. Reprinted with permission from reference [80]. Copyright (2016) Elsevier B.V. 


\subsection{Hydrogenation of Nitroaromatic Compounds}

Several organic nitroaromatic compounds can be easily hydrogenated to create the corresponding amino compounds on the UV-irradiated $\mathrm{TiO}_{2}$ in the presence of 2-propanol as a sacrificial hole scavenger (Scheme 2).

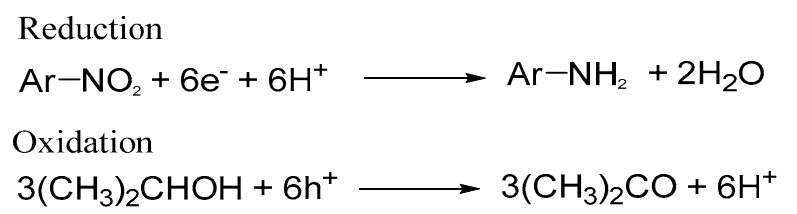

Scheme 2. Photocatalytic reduction of nitroaromatic compounds and oxidation of 2-propanol as a sacrificial hole scavenger.

Shiraishi et al. reported that some kinds of rutile $\mathrm{TiO}_{2}$ particles promote the highly efficient photocatalytic hydrogenation of nitroaromatic compounds [81,82]. They claimed that the oxygen vacancy sites on the rutile $\{110\}$ behave as the adsorption sites for the nitroaromatic compounds and the electron trap sites, resulting in the formation of aniline derivatives with significantly high yields of greater than $25 \%$ at $370 \mathrm{~nm}$ [81]. They also found that the activity of rutile particles depends on the number of defects on the particles [82]. The inner (bulk) defects behave as the deactivation sites for the recombination of electrons and holes, whereas the surface defects behave as the active reaction sites as well as the deactivation sites. As a result, the reaction rate is proportional to the ratio of the amount of surface defects to that of total defects $\left(N_{\text {surface }} / N_{\text {total }}\right)$ in the rutile $\mathrm{TiO}_{2}$ particles, which aligns with the report of Kong and coworkers [16].

Molinari and coworkers examined the selective hydrogenation of $\mathrm{NO}_{2}-\mathrm{C}_{6} \mathrm{H}_{4}-\mathrm{CHO}$, bearing the two reducible functional groups, $-\mathrm{NO}_{2}$ and $-\mathrm{CHO}$ [62]. They found that the nitro group was easily reduced by the trapped electrons at $\mathrm{Ti}_{\mathrm{ds}}$ within the bandgap, whereas the aldehyde group was reduced by electrons accumulated on CB. Therefore, the chemoselective reduction of functional groups can be controlled by the energy distribution patterns of $\mathrm{Ti}_{\mathrm{ds}}$, which may depend on the type of $\mathrm{TiO}_{2}$ powders. The selective reduction of functional groups is difficult to achieve through conventional thermal catalysis. Therefore, this topic is an interesting issue for chemoselective photocatalysis.

\section{Summary and Potential for the Development of Efficient Photocatalysis}

According to the reports of Kong et al. [16] and Shiraishi et al. [82], the photocatalytic efficiencies increased with increasing the ratio of the amount of surface to bulk defects $\left(N_{\text {surface }} / N_{\text {bulk }}\right)$ or the amount of surface to total defects $\left(N_{\text {surface }} / N_{\text {total }}\right)$. For example, molecular oxygen $\left(\mathrm{O}_{2}\right)$ in a gaseous phase would be easily adsorbed on the surface $\mathrm{Ti}_{\mathrm{ds}}$ and reduced by electrons $\mathrm{Ti}_{\mathrm{ds}}{ }^{3+}$ and $\mathrm{e}_{\mathrm{cb}}{ }^{-}$, resulting in the efficient formation of ROS, which oxidize benzene efficiently [16]. Further, the surface $\mathrm{Ti}_{\mathrm{ds}}$ behaves as the active reaction site in the efficient reduction of nitrobenzene [81]. Thus, the surface defects favorably act as adsorption sites as well as reaction sites.

In addition, the relative position between the energy distributions of $\mathrm{Ti}_{\mathrm{ds}}$ and the acceptor level (reduction potential) of substrates should be appropriate as indicated in Figure 5 [72]. The electrons accumulated in $\mathrm{CB}$ and trapped at shallow $\mathrm{Ti}_{\mathrm{ds}}$ can easily participate in the reaction, whereas those trapped at deep $\mathrm{Ti}_{\mathrm{ds}}$ cannot [63]. These unreacted electrons remain at the deep $\mathrm{Ti}_{\mathrm{ds}}$ sites and exhibit an extremely long lifetime in alcohols. Thus, the shallow traps enhance photocatalytic activity, while the deep traps cause a reduction. Furthermore, Amano et al. proposed that the creation of shallow $\mathrm{Ti}_{\mathrm{ds}}$ greatly enhances electrical conductivity, thereby facilitating the charge transport and separation caused by the formation of band bending in the space charge layer at the $\mathrm{TiO}_{2}$-liquid interface $[14,15]$.

In conclusion, the development of highly active photocatalysts necessitates precise control of the structural properties; the density of surface shallow traps should be maximized and the density of deep traps as well as inner (bulk) traps minimized, as proposed by Ohtani [83]. One of the 
promising strategies for meeting these requirements is the use of highly uniform $\mathrm{TiO}_{2}$ nanocrystals with specific exposure of the reactive facets [42,84-87]. In particular, the anatase $\{101\}$ and $\{001\}$ facets have been reported to be favorable for the reductive and oxidative reactions in $\mathrm{TiO}_{2}$ photocatalysis, respectively [87-91]. If the reductive and oxidative facets could be selectively covered with a large amount of the active shallow $\mathrm{Ti}_{\mathrm{ds}}$ and the terminal $\mathrm{Ti}-\mathrm{O}_{\mathrm{s}} \mathrm{H}$ hole trapping sites, respectively, the photocatalytic activity on the $\mathrm{TiO}_{2}$ nanocrystals would be greatly enhanced by the effective electron-hole charge separation, followed by the subsequent charge transfer reactions at the specific reductive and oxidative sites. Therefore, special attention should be directed toward the development of $\mathrm{TiO}_{2}$ nanocrystals with precisely controlled facets.

Acknowledgments: The works in references $[63,72,73,77,78,80]$ were supported by JSPS KAKENHI Grant Numbers 21590052 and 24590067.

Conflicts of Interest: The author declares no conflict of interest.

\section{References}

1. Fujishima, A.; Honda, K. Electrochemical photolysis of water at a semiconductor electrode. Nature 1972, 238, 37-38. [CrossRef] [PubMed]

2. Kudo, A.; Miseki, Y. Heterogeneous photocatalyst materials for water splitting. Chem. Soc. Rev. 2009, 38, 253-278. [CrossRef] [PubMed]

3. Fujishima, A.; Zhang, X.; Tryk, D. Heterogeneous photocatalysis: From water photolysis to applications in environmental cleanup. Int. J. Hydrog. Energy 2007, 32, 2664-2672. [CrossRef]

4. Grätzel, M. Recent advances in sensitized mesoscopic solar cells. Acc. Chem. Res. 2009, 42, $1788-1798$. [CrossRef] [PubMed]

5. Hagfeldt, A.; Boschloo, G.; Sun, L.; Kloo, L.; Pettersson, H. Dye-sensitized solar cells. Chem. Rev. 2010, 110, 6595-6663. [CrossRef] [PubMed]

6. Hoffmann, M.; Martin, S.; Choi, W.; Bahnemann, D. Environmental applications of semiconductor photocatalysis. Chem. Rev. 1995, 95, 69-96. [CrossRef]

7. Sakata, T. Photocatalysis of irradiated semiconductor surfaces: Its application to water splitting and some organic reactions. J. Photochem. 1985, 29, 205-215. [CrossRef]

8. Kisch, H. Semiconductor photocatalysis for organic synthesis advances in photochemistry. Adv. Photochem. 2001, 26, 93-143.

9. Palmisano, G.; Augugliaro, V.; Pagliaro, M.; Palmisano, L. Photocatalysis: A promising route for 21st century organic chemistry. Chem. Commun. 2007, 3425-3437. [CrossRef] [PubMed]

10. Kohtani, S.; Yoshioka, E.; Miyabe, H. Photocatalytic hydrogenation on semiconductor particles. Hydrogenation 2012, 291-308. [CrossRef]

11. Kisch, H. Semiconductor photocatalysis-mechanistic and synthetic aspects. Angew. Chem. Int. Ed. 2013, 52, 812-847. [CrossRef] [PubMed]

12. Fujishima, A.; Rao, T.; Tryk, D. Titanium dioxide photocatalysis. J. Photochem. Photobiol. C 2000, 1, 1-21. [CrossRef]

13. Thompson, T.; Yates, J. Surface science studies of the photoactivation of $\mathrm{TiO}_{2}$ new photochemical processes. Chem. Rev. 2006, 106, 4428-4453. [CrossRef] [PubMed]

14. Amano, F.; Nakata, M.; Yamamoto, A.; Tanaka, T. Effect of $\mathrm{Ti}^{3+}$ ions and conduction band electrons on photocatalytic and photoelectrochemical activity of rutile titania for water oxidation. J. Phys. Chem. C 2016, 120, 6467-6474. [CrossRef]

15. Amano, F.; Nakata, M.; Yamamoto, A.; Tanaka, T. Rutile titanium dioxide prepared by hydrogen reduction of degussa P25 for highly efficient photocatalytic hydrogen evolution. Catal. Sci. Technol. 2016, 6, 5693-5699. [CrossRef]

16. Kong, M.; Li, Y.; Chen, X.; Tian, T.; Fang, P.; Zheng, F.; Zhao, X. Tuning the relative concentration ratio of bulk defects to surface defects in $\mathrm{TiO}_{2}$ nanocrystals leads to high photocatalytic efficiency. J. Am. Chem. Soc. 2011, 133, 16414-16417. [CrossRef] [PubMed]

17. Diebold, U. The surface science of titanium dioxide. Surf. Sci. Rep. 2003, 48, 53-229. [CrossRef] 
18. Henderson, M. A Surface science perspective on $\mathrm{TiO}_{2}$ photocatalysis. Surf. Sci. Rep. 2011, 66, $185-297$. [CrossRef]

19. Nowotny, M.K.; Sheppard, L.R.; Bak, T.; Nowotny, J. Defect chemistry of titanium dioxide. Application of defect engineering in processing of $\mathrm{TiO}_{2}$-based photocatalysts. J. Phys. Chem. C 2008, 112, 5275-5300. [CrossRef]

20. Nowotny, J.; Alim, M.; Bak, T.; Idris, M.; Ionescu, M.; Prince, K.; Sahdan, M.; Sopian, K.; Mat Teridi, M.; Sigmund, W. Defect chemistry and defect engineering of $\mathrm{TiO}_{2}$-based semiconductors for solar energy conversion. Chem. Soc. Rev. 2015, 44, 8424-8442. [CrossRef] [PubMed]

21. Schneider, J.; Matsuoka, M.; Takeuchi, M.; Zhang, J.; Horiuchi, Y.; Anpo, M.; Bahnemann, D. Understanding $\mathrm{TiO}_{2}$ photocatalysis: Mechanisms and materials. Chem. Rev. 2014, 114, 9919-9986. [CrossRef] [PubMed]

22. Tamaki, Y.; Furube, A.; Murai, M.; Hara, K.; Katoh, R.; Tachiya, M. Dynamics of efficient electron-hole separation in $\mathrm{TiO}_{2}$ nanoparticles revealed by femtosecond transient absorption spectroscopy under the weak-excitation condition. Phys. Chem. Chem. Phys. 2007, 9, 1453-1460. [CrossRef] [PubMed]

23. Tamaki, Y.; Hara, K.; Katoh, R.; Tachiya, M.; Furube, A. Femtosecond visible-to-IR spectroscopy of $\mathrm{TiO}_{2}$ nanocrystalline films: Elucidation of the electron mobility before deep trapping. J. Phys. Chem. C 2009, 113, 11741-11746. [CrossRef]

24. Tamaki, Y.; Furube, A.; Murai, M.; Hara, K.; Katoh, R.; Tachiya, M. Direct observation of reactive trapped holes in $\mathrm{TiO}_{2}$ undergoing photocatalytic oxidation of adsorbed alcohols: Evaluation of the reaction rates and yields. J. Am. Chem. Soc. 2006, 128, 416-417. [CrossRef] [PubMed]

25. Ma, Y.; Wang, X.; Jia, Y.; Chen, X.; Han, H.; Li, C. Titanium dioxide-based nanomaterials for photocatalytic fuel generations. Chem. Rev. 2014, 114, 9987-10043. [CrossRef] [PubMed]

26. Chen, X.; Liu, L.; Yu, P.Y.; Mao, S.S. Increasing solar absorption for photocatalysis with black hydrogenated titanium dioxide nanocrystals. Science 2011, 331, 746-750. [CrossRef] [PubMed]

27. Chen, X.; Liu, L.; Huang, F. Black titanium dioxide $\left(\mathrm{TiO}_{2}\right)$ nanomaterials. Chem. Soc. Rev. 2015, 44, 1861-1885. [CrossRef] [PubMed]

28. Zhou, W.; Li, W.; Wang, J.-Q.; Qu, Y.; Yang, Y.; Xie, Y.; Zhang, K.; Wang, L.; Fu, H.; Zhao, D. Ordered mesoporous black $\mathrm{TiO}_{2}$ as highly efficient hydrogen evolution photocatalyst. J. Am. Chem. Soc. 2014, 136, 9280-9283. [CrossRef] [PubMed]

29. Di Valentin, C.; Pacchioni, G.; Selloni, A. Reduced and n-type doped $\mathrm{TiO}_{2}$ : Nature of $\mathrm{Ti}^{3+}$ species. J. Phys. Chem. C 2009, 113, 20543-20552. [CrossRef]

30. Wendt, S.; Sprunger, P.T.; Lira, E.; Madsen, G.K.H.; Li, Z.; Hansen, J.O.; Matthiesen, J.; Blekinge Rasmussen, A.; Laegsgaard, E.; Hammer, B.; et al. The role of interstitial sites in the Ti3d defect state in the band gap of titania. Science 2008, 320, 1755-1759. [CrossRef] [PubMed]

31. Chen, X.; Zhao, D.; Liu, K.; Wang, C.; Liu, L.; Li, B.; Zhang, Z.; Shen, D. Laser-modified black titanium oxide nanospheres and their photocatalytic activities under visible light. ACS Appl. Mater. Interfaces 2015, 7, 16070-16077. [CrossRef] [PubMed]

32. Filice, S.; Compagnini, G.; Fiorenza, R.; Scirè, S.; D’Urso, L.; Fragalà, M.E.; Russo, P.; Fazio, E.; Scalese, S. Laser processing of $\mathrm{TiO}_{2}$ colloids for an enhanced photocatalytic water splitting activity. J. Colloid Interface Sci. 2017, 489, 131-137. [CrossRef] [PubMed]

33. Russo, P.; Liang, R.; He, R.X.; Zhou, Y.N. Phase transformation of $\mathrm{TiO}_{2}$ nanoparticles by femtosecond laser ablation in aqueous solutions and deposition on conductive substrates. Nanoscale 2017, 9, 6167-6177. [CrossRef] [PubMed]

34. Zhang, D.; Liu, J.; Li, P.; Tian, Z.; Liang, C. Recent advances in surfactant-free, surface-charged, and defect-rich catalysts developed by laser ablation and processing in liquids. ChemNanoMat 2017, 3, 512-533. [CrossRef]

35. Weiler, B.; Gagliardi, A.; Lugli, P. Kinetic monte carlo simulations of defects in anatase titanium dioxide. J. Phys. Chem. C 2016, 120, 10062-10077. [CrossRef]

36. Deskins, N.A.; Rousseau, R.; Dupuis, M. Localized electronic states from surface hydroxyls and polarons in $\mathrm{TiO}_{2}$ (110). J. Phys. Chem. C 2009, 113, 14583-14586. [CrossRef]

37. Deskins, N.A.; Rousseau, R.; Dupuis, M. Distribution of $\mathrm{Ti}^{3+}$ surface sites in reduced $\mathrm{TiO}_{2}$. J. Phys. Chem. C 2011, 115, 7562-7572. [CrossRef]

38. Howe, R.; Grätzel, M. EPR observation of trapped electrons in colloidal titanium dioxide. J. Phys. Chem. 1985, 89, 4495-4499. [CrossRef] 
39. Hurum, D.; Agrios, A.; Gray, K.; Rajh, T.; Thurnauer, M. Explaining the enhanced photocatalytic activity of degussa P25 mixed-phase $\mathrm{TiO}_{2}$ using EPR. J. Phys. Chem. B 2003, 107, 4545-4549. [CrossRef]

40. Berger, T.; Sterrer, M.; Diwald, O.; Knözinger, E.; Panayotov, D.; Thompson, T.L.; Yates, J.T. Light-induced charge separation in anatase $\mathrm{TiO}_{2}$ particles. J. Phys. Chem. B 2005, 109, 6061-6068. [CrossRef] [PubMed]

41. Li, G.; Dimitrijevic, N.; Chen, L.; Nichols, J.; Rajh, T.; Gray, K. The important role of tetrahedral Ti ${ }^{4+}$ sites in the phase transformation and photocatalytic activity of $\mathrm{TiO}_{2}$ nanocomposites. J. Am. Chem. Soc. 2008, 130, 5402-5403. [CrossRef] [PubMed]

42. Gordon, T.; Cargnello, M.; Paik, T.; Mangolini, F.; Weber, R.; Fornasiero, P.; Murray, C. Nonaqueous synthesis of $\mathrm{TiO}_{2}$ nanocrystals using $\mathrm{TiF}_{4}$ to engineer morphology, oxygen vacancy concentration, and photocatalytic activity. J. Am. Chem. Soc. 2012, 134, 6751-6761. [CrossRef] [PubMed]

43. Szczepankiewicz, S.; Colussi, A.J.; Hoffmann, M. Infrared spectra of photoinduced species on hydroxylated titania surfaces. J. Phys. Chem. B 2000, 104, 9842-9850. [CrossRef]

44. Szczepankiewicz, S.; Moss, J.; Hoffmann, M. Slow surface charge trapping kinetics on irradiated $\mathrm{TiO}_{2}$. J. Phys. Chem. B 2002, 106, 2922-2927. [CrossRef]

45. Takeuchi, M.; Martra, G.; Coluccia, S.; Anpo, M. Verification of the photoadsorption of $\mathrm{H}_{2} \mathrm{O}$ molecules on $\mathrm{TiO}_{2}$ semiconductor surfaces by vibrational absorption spectroscopy. J. Phys. Chem. C 2007, 111, 9811-9817. [CrossRef]

46. Panayotov, D.; Burrows, S.; Morris, J. Infrared spectroscopic studies of conduction band and trapped electrons in UV-photoexcited, H-atom n-doped, and thermally reduced $\mathrm{TiO}_{2}$. J. Phys. Chem. C 2012, 116, 4535-4544. [CrossRef]

47. Savory, D.; McQuillan, A.J. Influence of formate adsorption and protons on shallow trap infrared absorption (STIRA) of anatase $\mathrm{TiO}_{2}$ during photocatalysis. J. Phys. Chem. C 2013, 117, 23645-23656. [CrossRef]

48. Litke, A.; Hensen, E.J.M.; Hofmann, J. Role of dissociatively adsorbed water on the formation of shallow trapped electrons in $\mathrm{TiO}_{2}$ photocatalysts. J. Phys. Chem. C 2017, 121, 10153-10162. [CrossRef] [PubMed]

49. Takeuchi, M.; Deguchi, J.; Sakai, S.; Anpo, M. Effect of $\mathrm{H}_{2} \mathrm{O}$ vapor addition on the photocatalytic oxidation of ethanol, acetaldehyde and acetic acid in the gas phase on $\mathrm{TiO}_{2}$ semiconductor powders. Appl. Catal. B Environ. 2010, 96, 218-223. [CrossRef]

50. Mohamed, H.; Dillert, R.; Bahnemann, D. Reaction dynamics of the transfer of stored electrons on $\mathrm{TiO}_{2}$ nanoparticles: A stopped flow study. J. Photochem. Photobiol. A Chem. 2011, 217, 271-274. [CrossRef]

51. Mohamed, H.; Mendive, C.; Dillert, R.; Bahnemann, D. Kinetic and mechanistic investigations of multielectron transfer reactions induced by stored electrons in $\mathrm{TiO}_{2}$ nanoparticles: A stopped flow study. J. Phys. Chem. A 2011, 115, 2139-2147. [CrossRef] [PubMed]

52. Knorr, F.; Mercado, C.; McHale, J. Trap-state distributions and carrier transport in pure and mixed-phase $\mathrm{TiO}_{2}$ : Influence of contacting solvent and interphasial electron transfer. J. Phys. Chem. C 2008, 112, 12786-12794. [CrossRef]

53. Leytner, S.; Hupp, J. Evaluation of the energetics of electron trap states at the nanocrystalline titanium dioxide/aqueous solution interface via time-resolved photoacoustic spectroscopy. Chem. Phys. Lett. 2000, 330, 231-236. [CrossRef]

54. Murakami, N.; Prieto Mahaney, O.; Torimoto, T.; Ohtani, B. Photoacoustic spectroscopic analysis of photoinduced change in absorption of titanium(IV) oxide photocatalyst powders: A novel feasible technique for measurement of defect density. Chem. Phys. Lett. 2006, 426, 204-208. [CrossRef]

55. Murakami, N.; Prieto Mahaney, O.; Abe, R.; Torimoto, T.; Ohtani, B. Double-beam photoacoustic spectroscopic studies on transient absorption of titanium(IV) oxide photocatalyst powders. J. Phys. Chem. C 2007, 111, 11927-11935. [CrossRef]

56. Nitta, A.; Takase, M.; Takashima, M.; Murakami, N.; Ohtani, B. A fingerprint of metal-oxide powders: Energy-resolved distribution of electron traps. Chem. Commun. 2016, 52, 12096-12099. [CrossRef] [PubMed]

57. Pang, C.; Lun Pang, C.; Lindsay, R.; Thornton, G. Chemical reactions on rutile $\mathrm{TiO}_{2}$ (110). Chem. Soc. Rev. 2008, 37, 2328-2353. [CrossRef] [PubMed]

58. Papageorigiou, A.; Papageorgiou, A.C.; Beglitis, N.S.; Pang, C.L.; Teobaldi, G.; Cabailh, G.; Chen, Q.; Fisher, A.J.; Hofer, W.A.; Thornton, G. Electron traps and their effect on the surface chemistry of $\mathrm{TiO}_{2}(110)$. Proc. Natl. Acad. Sci. USA 2010, 107, 2391-2396. [CrossRef] [PubMed]

59. Setvin, M.; Aschauer, U.; Scheiber, P.; Li, Y.F.; Hou, W.; Schmid, M.; Selloni, A.; Diebold, U. Reaction of $\mathrm{O}_{2}$ with subsurface oxygen vacancies on $\mathrm{TiO}_{2}$ anatase (101). Science 2013, 341, 988-991. [CrossRef] [PubMed] 
60. Ikeda, S.; Sugiyama, N.; Murakami, S.; Kominami, H.; Kera, Y.; Noguchi, H.; Uosaki, K.; Torimoto, T.; Ohtani, B. Quantitative analysis of defective sites in titanium(IV) oxide photocatalyst powders. Phys. Chem. Chem. Phys. 2003, 5, 778-783. [CrossRef]

61. Wang, H.; He, J.; Boschloo, G.; Lindström, H.; Hagfeldt, A.; Lindquist, S.-E. Electrochemical investigation of traps in a nanostructured $\mathrm{TiO}_{2}$ film. J. Phys. Chem. B 2001, 105, 2529-2533. [CrossRef]

62. Molinari, A.; Maldotti, A.; Amadelli, R. Probing the role of surface energetics of electrons and their accumulation in photoreduction processes on $\mathrm{TiO}_{2}$. Chem. Eur. J. 2014, 20, 7759-7765. [CrossRef] [PubMed]

63. Kohtani, S.; Yoshioka, E.; Saito, K.; Kudo, A.; Miyabe, H. Adsorptive and kinetic properties on photocatalytic hydrogenation of aromatic ketones upon UV irradiated polycrystalline titanium dioxide: Differences between acetophenone and its trifluoromethylated derivative. J. Phys. Chem. C 2012, 116, 17705-17713. [CrossRef]

64. Lemon, B.; Hupp, J. Photochemical quartz crystal microbalance study of the nanocrystalline titanium dioxide semiconductor electrode/water interface: Simultaneous photoaccumulation of electrons and protons. J. Phys. Chem. 1996, 100, 14578-14580. [CrossRef]

65. Jimenez, J.; Jiménez, J.; Bourret, G.; Berger, T.; McKenna, K. Modification of charge trapping at particle/particle interfaces by electrochemical hydrogen doping of nanocrystalline $\mathrm{TiO}_{2}$. J. Am. Chem. Soc. 2016, 138, 15956-15964. [CrossRef] [PubMed]

66. Peiró, A.; Colombo, C.; Doyle, G.; Nelson, J.; Mills, A.; Durrant, J. Photochemical reduction of oxygen adsorbed to nanocrystalline $\mathrm{TiO}_{2}$ films: A transient absorption and oxygen scavenging study of different $\mathrm{TiO}_{2}$ preparations. J. Phys. Chem. B 2006, 110, 23255-23263. [CrossRef] [PubMed]

67. Dung, D.; Ramsden, J.; Grätzel, M. Dynamics of interfacial electron-transfer processes in colloidal semiconductor systems. J. Am. Chem. Soc. 1982, 104, 2977-2985. [CrossRef]

68. Ilan, Y.; Meisel, D.; Czapski, G. The redox potential of the $\mathrm{O}_{2} / \mathrm{O}_{2}{ }^{-}$system in aqueous media. Isr. J. Chem. 1974, 12, 891-895. [CrossRef]

69. Hirakawa, H.; Hashimoto, M.; Shiraishi, Y.; Hirai, T. Photocatalytic conversion of nitrogen to ammonia with water on surface oxygen vacancies of titanium dioxide. J. Am. Chem. Soc. 2017, 139, 10929-10936. [CrossRef] [PubMed]

70. Hirakawa, H.; Hashimoto, M.; Shiraishi, Y.; Hirai, T. Selective nitrate-to-ammonia transformation on surface defects of titanium dioxide photocatalysts. ACS Catal. 2017, 7, 3713-3720. [CrossRef]

71. Burt, T.P.; Howden, N.J.K.; Worrall, F.; Whelan, M.J. Long-term monitoring of river water nitrate: How much data do we need? J. Environ. Monit. 2010, 12, 71-79. [CrossRef] [PubMed]

72. Kohtani, S.; Kamoi, Y.; Yoshioka, E.; Miyabe, H. Kinetic study on photocatalytic hydrogenation of acetophenone derivatives on titanium dioxide. Catal. Sci. Technol. 2014, 4, 1084-1091. [CrossRef]

73. Kohtani, S.; Yoshioka, E.; Saito, K.; Kudo, A.; Miyabe, H. Photocatalytic hydrogenation of acetophenone derivatives and diaryl ketones on polycrystalline titanium dioxide. Catal. Commun. 2010, 11, 1049-1053. [CrossRef]

74. Lewis, N. Progress in understanding electron-transfer reactions at semiconductor/liquid interfaces. J. Phys. Chem. B 1998, 102, 4843-4855. [CrossRef]

75. Hamann, T.; Gstrein, F.; Brunschwig, B.; Lewis, N. Measurement of the free-energy dependence of interfacial charge-transfer rate constants using $\mathrm{ZnO} / \mathrm{H}_{2} \mathrm{O}$ semiconductor/liquid contacts. J. Am. Chem. Soc. 2005, 127, 7815-7824. [CrossRef] [PubMed]

76. Ondersma, J.; Hamann, T. Measurements and modeling of recombination from nanoparticle $\mathrm{TiO}_{2}$ electrodes. J. Am. Chem. Soc. 2011, 133, 8264-8271. [CrossRef] [PubMed]

77. Kohtani, S.; Nishioka, S.; Yoshioka, E.; Miyabe, H. Dye-sensitized photo-hydrogenation of aromatic ketones on titanium dioxide under visible light irradiation. Catal. Commun. 2014, 43, 61-65. [CrossRef]

78. Kohtani, S.; Mori, M.; Yoshioka, E.; Miyabe, H. Photohydrogenation of acetophenone using coumarin dye-sensitized titanium dioxide under visible light irradiation. Catalysts 2015, 5, 1417-1424. [CrossRef]

79. Beier, P.; Alexandrova, A.; Zibinsky, M.; Surya Prakash, G.K. Nucleophilic difluoromethylation and difluoromethylenation of aldehydes and ketones using diethyl difluoromethylphosphonate. Tetrahedron 2008, 64, 10977-10985. [CrossRef] [PubMed]

80. Kohtani, S.; Kurokawa, T.; Yoshioka, E.; Miyabe, H. Photoreductive transformation of fluorinated acetophenone derivatives on titanium dioxide: Defluorination vs. reduction of carbonyl group. Appl. Catal. A Genel. 2016, 521, 68-74. [CrossRef] 
81. Shiraishi, Y.; Togawa, Y.; Tsukamoto, D.; Tanaka, S.; Hirai, T. Highly efficient and selective hydrogenation of nitroaromatics on photoactivated rutile titanium dioxide. ACS Catal. 2012, 2, 2475-2481. [CrossRef]

82. Shiraishi, Y.; Hirakawa, H.; Togawa, Y.; Sugano, Y.; Ichikawa, S.; Hirai, T. Rutile crystallites isolated from Degussa (Evonik) P25 $\mathrm{TiO}_{2}$ : Highly efficient photocatalyst for chemoselective hydrogenation of nitroaromatics. ACS Catal. 2013, 3, 2318-2326. [CrossRef]

83. Ohtani, B. Titania photocatalysis beyond recombination: A critical review. Catalysts 2013, 3, $942-953$. [CrossRef]

84. Yang, H.; Sun, C.; Qiao, S.; Zou, J.; Liu, G.; Smith, S.; Cheng, H.; Lu, G. Anatase $\mathrm{TiO}_{2}$ single crystals with a large percentage of reactive facets. Nature 2008, 453, 638-641. [CrossRef] [PubMed]

85. Amano, F.; Yasumoto, T.; Prieto Mahaney, O.-O.; Uchida, S.; Shibayama, T.; Ohtani, B. Photocatalytic activity of octahedral single-crystalline mesoparticles of anatase titanium(IV) oxide. Chem. Commun. 2009, 2311-2313. [CrossRef] [PubMed]

86. Liu, G.; Yang, H.; Pan, J.; Yang, Y.; Lu, G.Q.; Cheng, H.-M. Titanium dioxide crystals with tailored facets. Chem. Rev. 2014, 114, 9559-9612. [CrossRef] [PubMed]

87. Liu, J.; Olds, D.; Peng, R.; Yu, L.; Foo, G.; Qian, S.; Keum, J.; Guiton, B.; Wu, Z.; Page, K. Quantitative analysis of the morphology of $\{101\}$ and $\{001\}$ faceted anatase $\mathrm{TiO}_{2}$ nanocrystals and its implication on photocatalytic activity. Chem. Mater. 2017, 29, 5591-5604. [CrossRef]

88. Roy, N.; Sohn, Y.; Pradhan, D. Synergy of low-energy $\{101\}$ and high-energy $\{001\} \mathrm{TiO}_{2}$ crystal facets for enhanced photocatalysis. ACS Nano 2013, 7, 2532-2540. [CrossRef] [PubMed]

89. Li, C.; Koenigsmann, C.; Ding, W.; Rudshteyn, B.; Yang, K.; Regan, K.; Konezny, S.; Batista, V.; Brudvig, G.; Schmuttenmaer, C.; Kim, J.-H. Facet-dependent photoelectrochemical performance of $\mathrm{TiO}_{2}$ nanostructures: An experimental and computational study. J. Am. Chem. Soc. 2015, 137, 1520-1529. [CrossRef] [PubMed]

90. Zhou, P.; Zhang, H.; Ji, H.; Ma, W.; Chen, C.; Zhao, J. Modulating the photocatalytic redox preferences between anatase $\mathrm{TiO}_{2}\{001\}$ and $\{101\}$ surfaces. Chem. Commun. 2017, 53, 787-790. [CrossRef] [PubMed]

91. Chamtouri, M.; Kenens, B.; Aubert, R.; Lu, G.; Inose, T.; Fujita, Y.; Masuhara, A.; Hofkens, J.; Uji-i, H. Facet-dependent diol-induced density of states of anatase $\mathrm{TiO}_{2}$ crystal surface. ACS Omega 2017, 2, 4032-4038. [CrossRef] [PubMed] 